portadores de lesão semi-agressiva. A lesão óssea monostótica foi a mais freqüente $(86,3 \%)$ sendo o padrão radiográfico osteolítico predominante em 40 casos $(75,5 \%)$. Comprometimento de ossos longos foi observado em 36 exames $(67,9 \%)$. A localização metáfisária foi a mais freqüente, vista em 28 casos $(77,7 \%)$, destacando-se a metáfise distal do rádio $(34.5 \%)$ e a metáfise proximal do úmero $(32,4 \%)$. O acometimento de cães com idade entre 5 a 10 anos foi o mais freqüente $(61,4 \%)$, sendo que os animais de raças puras foram os mais acometidos (70,5\%), destacando-se Dogue Alemão (13,6\%), Fỉla Brasileiro $(11,4 \%)$ e Doberman $(9.1 \%)$. Dos 44 animais, 23 eram machos e 21 fêmeas. Dentre as alteraçòes radiográficas encontradas a ocorrência de fratura patológica foi vista em 11 casos $(24,5 \%)$. Com tal estudo pudemos concluir que o exame radiográfico constitui método importante para a detecção de lesão óssea agressiva, sendo estas freqüentes em nosso meio. Para definiçào de diagnóstico das lesões ósseas agressivas consideramos fundamental a realização de biópsias para análise histopatológica, bem como, a avaliação radiográfica do tórax e ultra-sonográfica do abdômen para pesquisas de metástases.

\title{
40 - Estudo radiográfico de lesões pulmonares na espécie canina
}

1- M.V. Residente do Hospital Veterinário da Universidade de Santo Amaro, São Paulo-SP

2- Professora Assistente da Disciplina de Diagnóstico por Imagem da Faculdade de Medicina Veterinária da Universidade de Santo Amaro, São Paulo-SP

A avaliaçào radiográfica das doenças pulmonares em pequenos animais está amparada por uma série de quadros patológicos. Essa relaçào é baseada nos diferentes quadros anatômicos radiográficos quanto as diferentes estruturas anatômicas dos pulmões são afetadas. $\mathrm{O}$ quadro relacionado ao diagnóstico está sendo utilizado por radiologistas por muitos anos e foi primeiramente utilizado em medicina veterinária em 1968. Quando esclarecidos esses quadros são extremamente úteis na formulação de diagnósticos diferenciais. Há também condiçōes patológicas dos pulmões que resultam em quadros mistos ou quadros que modificam-se de um tipo para outro num período de tempo. A correlação dos achados radiográficos com exame clínico e achados laboratoriais é imperativo para alcançar o diagnóstico correto. Foram avaliadas as radiografias do tórax de 460 animais da espécie canina, atendidos no Hospital Veterinário da Universidade de Santo Amaro, no período de janeiro de 1999 a dezembro de 2001, com o objetivo de analisar os aspectos radiográficos observados nas lesōes pulmonares, incluindo localizaçào e distribuiçào, e analisar a freqüência destes casos em nosso meio. Para melhor avaliação dos campos pulmonares os exames radiográficos foram constituídos das projeções laterais (decúbitos direito e esquerdo) e da projeçào ventrodorsal. Os aspectos radiográficos observados, quanto aos padròes de lesão, extensão, localização e distribuição, foram anotados em fichas individuais bem como informaçōes adicionais, como a ocorrência de alterações outras em cavidade torácica. Neste estudo observamos 91 casos $(19.8 \%)$ de lesões pulmonares; destes 34 casos $(37.4 \%)$ foram de padrão alveolar, $45(49.5 \%)$ foram de padrào intersticial, 3 casos $(3,3 \%)$ de padrão brônquico e 8 casos $(8.8 \%)$ foram considerados quadros mistos sem um padrão único predominante. O padrão pulmonar vascular não foi observado neste estudo. Concluímos que as doenças pulmonares intersticiais seguidas pelas doenças alveolares foram as mais freqüentes. Os padrões alveolares observados foram correlacionados principalmente a broncopneumonias, edemas, hemorragias e contusões pulmonares. Dentre os casos de lesão pulmonar intersticial, o padrão difuso foi observado em 9 casos $(9.9 \%)$, sendo estes correlacionados a pneumonias intersticiais, edema e contusões pulmonares. Em 36 exames $(39.6 \%)$ observamos padrão intersticial nodular sendo que este padrão é freqüentemente associado a quadros neoplásicos e principalmente a metástases pulmonares. Consideramos neste estudo que um número bastante expressivo de alterações radiográficas pulmonares foi decorrente a quadros de metástase pulmonar. 